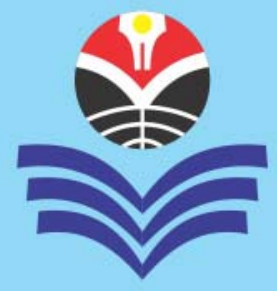

\title{
Esther: Biblical Model for Women Leadership Role in Contemporary Nigeria
}

ABSTRACT: The paper examined critically the story of Esther in the Bible, who delivered her nation when they were being threatened with total annihilation. The patriotism, faith, prayer, and determination she combined to deliver her nation were examined. With the background story of Esther given, the paper noted that leaders of women's groups could use Esther as a role model to rescue Nigeria from total collapse, especially now that the peace of the nation is being threatened by Boko Haram insurgency. To make this more challenging to the women folk, the paper appraised the positive contributions of some women in the pre-colonial, colonial, and post-colonial periods. The paper observed that women who were appointed to the key administrative and political positions at this period performed creditably. However, the paper observed that some women started off well, but veered off to corruption. It is, therefore, noted that the fact that some women did not play their roles correctly does not mean there could not be a change. It is against this background that the paper recommended Biblical leadership model of Esther, which is a model of determination, self-sacrifice, prayer, humility, and righteousness. Equally, women were encouraged to use their positions to improve, although they are the less privileged in the society, and to always take advantage of any circumstance.

KEY WORD: Esther, women leadership, role model, patriotism, and self-sacrifice.

ABTRAKSI: “Esther: Teladan dalam Alkitab untuk Peran Kepemimpinan Perempuan di Negara Nigeria Kini”. Makalah ini mengkaji secara kritis kisah Ester dalam Alkitab, yang menyelamatkan bangsanya ketika terancam dalam kehancuran total. Patriotisme, iman, doa, dan tekad yang Esther lakukan untuk membebaskan bangsanya itu dikaji dalam penelitian ini. Dengan latar belakang cerita Ester, makalah ini mencatat bahwa pemimpin kelompok perempuan bisa menggunakan Esther sebagai model atau teladan untuk menyelamatkan Nigeria dari kehancuran total, terutama sekarang ini karena perdamaian bangsa sedang terancam oleh pemberontakan Boko Haram. Untuk menjadikan hal ini lebih menantang bagi kaum perempuan, makalah ini menilai kontribusi positif dari beberapa wanita pada zaman pra-kolonial, zaman kolonial, dan zaman pasca-kolonial. Makalah ini mengamati bahwa wanita yang ditunjuk untuk menempati posisi administrasi dan politik penting pada periode ini dapat dipercaya. Namun, makalah ini juga mengamati bahwa beberapa wanita memulainya dengan baik, tetapi kemudian melakukan penyimpangan dalam korupsi. Oleh karena itu, perlu dicatat bahwa fakta beberapa wanita tidak memainkan peran mereka dengan benar tidak pula berarti bahwa perubahan tidak mungkin. Dengan latar belakang ini, makalah merekomendasikan model kepemimpinan Esther dalam Alkitab, yang merupakan teladan dalam keteguhan, pengorbanan diri, doa, kerendahan hati, dan kebenaran. Semua perempuan didorong untuk sama-sama menggunakan posisi mereka agar lebih baik, meskipun mereka adalah orang yang kurang beruntung dalam masyarakat, dan untuk selalu mengambil keuntungan dari setiap keadaan.

KATA KUNCI: Esther, kepemimpinan wanita, teladan, patriotisme, dan pengorbanan diri.

About the Author: Dr. Adesanya Ibiyinka Olusola is a Lecturer at the Department of Religious Studies, Ekiti State University, Ado-Ekiti, Nigeria. For academic interests, the author is able to be contacted via mobile phone at: +2348133946799 or e-mail at: olusolaibiyinka@yahoo.com

How to cite this article? Olusola, Adesanya Ibiyinka. (2016). "Esther: Biblical Model for Women Leadership Role in Contemporary Nigeria” in MIMBAR PENDIDIKAN: Jurnal Indonesia untuk Kajian Pendidikan, Vol.1(1) Maret, pp.77-86. Bandung, Indonesia: UPI Press.

Chronicle of the article: Accepted (February 11, 2016); Revised (February 21, 2016); and Published (March 11, 2016). 


\section{INTRODUCTION}

Numerous behavioral studies have found women to be effective leaders. Specifically, P. Yukh Levy (2010) said, "women have a feminine advantage over men in leadership positions because they are more interpersonally sensitive and nurturing" (Levy, 2010:374). These attributes possibly have helped most women to excel in their different areas of endeavors. In the leadership positions, women all over the world have fought for a place and this they have been able to achieve. Women today are operating almost at the same level with their male counterparts; they are part of the decisionmaking and are equally accorded the same respect (Longe, 2015). Women were known to have occupied very influential political offices, including military, academics, private, and public sectors/organizations.

Meanwhile, the appreciation and justification of the virtue of women's complete and confirmed integrity by several studies in the behavioral and social science has come with a recession, as women in some leadership positions have continually been linked with some vices (Terwase, 2010). Also, as rightly observed by E. Babajide (2000), the lingering misconception in Nigeria is that women lack dependability. This was said to be the reason, the men folks attributed to their poor selection and slow promotion to top hierarchy, occupational status in organization which are largely based on the male model type of leadership that emphasized ambition reliability and risk taking (Babajide, 2000).

Therefore, with this lingering assumption about women and for the fact that some women in recent time have not lived up to expectations, then, there is a need for a radical restructuring of women's orientation as Nigeria enter into a new century and a new era of history and leadership. This paper is, therefore, a clarion call for action, the rationale of which is proposing a strategy for good and effective leadership among women.
The question then is "is it possible to have virile and effective leaders among women in Nigeria considering the level of corruption in our society?" The answer to an extent is in the affirmative; it is very possible. Esther, in the Bible, salvages her people from total annihilation by the enemy.

Consequently, the purpose of this paper is to examine the role played by Esther in the Bible. This will be followed by taking a cursory look at the concept of leadership and performance of some Nigerian women leaders so far. Finally, with the call on everyone by government and individuals to contribute to war against indiscipline, the paper will propose the religious strategy model of Esther in the Bible that could assist women in managing the leadership positions.

\section{CONCEPTUAL CLARIFICATION}

What is Leadership? Like any other terminology, leadership as a concept can be defined in various ways and many scholars have given it different definition based on the way it is being perceived. This will, therefore, be considered one after the other and at the end give the summary of all. According to E. Atimono (1981), leadership in its broadest sense means a group of people functionally responsible for running a nationstate, heads of families, groups, mosques, churches, pressure groups, political parties, and local state, national and international institutions (Atimono, 1981).

Leadership, according to S. Zeitchick (2012), is inspiring others to pursue your vision in the parameters you set, to the extent that it becomes a shared vision, and a shared success (Zeitchik, 2012). K. Kruse (2013), on the other hand, defines it as a process of social influence, which maximizes the efforts of others, towards the achievement of a goal (Kruse, 2013:3).

Sharing the same view, G. Northhouse (2007) views it as process, whereby an individual influences a group of individual to achieve a common goal (Northouse, 2007:3). 
For further clarification, J. Osuntokun (1987) states that:

Leadership can be defined in terms of direction and example provided by any person or group of persons who are chosen by an accident of history find themselves at the helm of affairs in a country or any vital part of it or in departments or institutions delegated to them for the purpose of overall development and good government of the country (Osuntokun, 1987:14).

Lastly, A.R.O. Olayiwola (2013) gives the attributes of leadership to include the following: (1) the existence in an individual of a clear set of ideas, values, aspirations reflecting those of the majority who are the subject of followership; (2) the existence of practical, purposeful initiative by the individual, reflecting the objectives of held ideas, values, and aspirations; and (3) the existence of concrete achievements involving the extent to which intended effects are produced by the leaders (Olayiwola, 2013:54).

Leaders, however, are expected to carry out this process by applying the following: access changes in the environment; adapt organization to external changes or problems; share responsibility; implement organizational mission; and adapt structure to generate organizational contributions to society (Direland \& Hitt, 2005:63).

The above reflects or focuses on what leaders, often top-level or positional leaders, need to do to accomplish effective and/or moral leadership. These forms of leadership one wants to believe could be found in the life of Esther, as she was determined, resolute, and transformational. It is in view of this that this paper would take a look at the leadership style of Esther in the Bible.

\section{WHO WAS ESTHER}

The Bible depicts Esther as a Jewish orphan, who was raised in the house of her uncle Mordecai. The midrash add, according to Esther Ralbah, 6:5, B.T. Megillah, 13a, that Esther father died during her mother's pregnancy and the mother too died during childbirth (cited in Lockyer, 1971). As a result of her mother's death, Mordecai had to care for Esther's nursing.

According to one tradition, Gen Rabbah, 30:5, he could not find a wet nurse and he himself miraculously had milk and nursed her (cited in Lockyer, 1971). The book of Esther (2:7) relates that Esther had two names. The second name of Esther is Hadassah. The Rabbis explained in B.T. Megillah, 13a, that she was given this name by the Gentiles, after the celestial body Istahar (cited by Lockyer, 1971). Also, it was recorded that she was so called because she was righteous, and the righteous are called "myrtles".

Esther became the queen of Xerxes, in some respects the greatest of the Persian kings. She was brought up at Susa by her cousin Mordecai, who seems to have held a position among the lower officials of the royal palace. Vashti, Xerxes former queen was divorced and the most beautiful virgins formally the province of the empire was brought to the palace of Susa that the king might select her successor. The choice fell upon the Jewish maiden. Soon after her ascension, a great crisis occurred in the history of the Jews (Lockyer, 1971:53).

The Great Crisis that Called for the Intervention of Esther. Esther is noted as the one responsible for the deliverance of Israel in the darkness of night. She was ready to endanger herself and even to give her life to save her people. The Rabbis described at length Esther's activities after she learnt of Haman's decree against the Jews. The book of Esther (4.4) reports that when Esther learnt that Mordecai was wearing sackcloth, "the queen was greatly agitated" (cited in Lockyer, 1971).

According to the Babylonian tradition, in B.T. Megillah, 15a, she saw menstrual blood (cited in Lockyer, 1971). In the Erez Israel tradition, she miscarried the fetus she bore in her womb (the offspring of Ahasuerus, Esth 
Rabbah, 8:13). According to other traditions, in B.T. Megillah, "her bowels were loosened" or "her strength weaned" (cited in Lockyer, 1971).

In the midrash reenactment, Esther sent a message to Mordecai, in which she asked him whether Israel had transgressed one of the commandments of the Torah. She greatly feared to appear before Ahasuerus. Esther asked Mordecai to fast for three days, even though the third day was the first day of the holiday of Passover. Esther herself observed the commandment of search for the favor of God. Before she went to Ahasuerus, Esther uttered the following prayer:

O Lord, the God of Israel, who has reigned from days of yore and created the universe, help please. Your handmaid who has remained an orphan without father and mother, and who is compared to a pauper who begs from door to door. Verily I seek your mercy from indoor to window in the house of Ahasuerus. And you, O Lord, bring success to this your poor handmaiden. Save the flock of your pasture from these foes who have risen against us for nothing prevents you from winning a victory by many or by few (cited in Lockyer, 1971:52).

The combined wisdom of Mordecai and Esther's courage became the means of lightening the load of the Jews under Persian rule. With Mordecai, Esther shared faith in the high destiny of Israel as a nation. Haman, the chief court favorite, was the Jews enemy - the Old Testament of Adolph Hitler - and conceived a plan to massacre the Jews en bloc. Exhorted by Mordecai, Esther revealed her Jewish nationality to the king and this courageous action brought about a complete reversal of the decree (Lockyer, 1971).

Haman was executed, Mordecai was honored by the king, and Esther's position as Queen was considerably strengthened. One cannot but agree with the summary of Esther that reads:

As an historical character, Esther is the supreme heroine who delivers her nation from disaster; as woman, she is that rare individual, a mixture of charm, strength and guile: a human being whose character is secure from the rot of wealth, prosperity and power (Lockyer, 1971:53).

Therefore, it could be said at this juncture that Esther illuminated Israel like the light of dawn, while this light itself was like darkness for the nations of the world. Esther dared to risk death for her people and so escaped dying with. By her patriotism, she won for her nation a great deliverance, and God used her as an instrument of His providence for the working out of a glorious purpose.

Established facts to be gleaned from Esther's narrative: (1) Esther's goal was life and so was moved by love to save her people; (2) Esther dared to take a stand and through her beauty, courage and skill she persuaded the king to save her people's lives; (3) Esther took action for the welfare of her people, the Jews; (4) Esther loved and clung to, although she concealed this, her despised but honorable descent; (5) She was a true patriot and, in the hour of crisis, was not ashamed to own her race in spite of her position as the queen; and (6) Esther was a leader by example, a woman of clear judgment, of magnificent self-control, and capable of the noblest self-sacrifices.

On this H.V. Morton has this to say:

When a person has gone up in the world and has achieved a position of power and eminence, it requires strength and beauty of character for that person still to love and remember the simple people from whom he, or she, sprang. Humble girls have often married rich men and have forgotten their origins. They have, in fact, been ashamed of anything that might remind them of it (in Lockyer, 1971:53).

\section{AN OVERVIEW OF SOME NIGERIAN WOMEN IN LEADERSHIP POSITIONS}

This aspect of the work will focus on women in Nigeria, who have played leadership roles in governance. This is mainly because women in politics have been topical issues in Nigeria since Independence. 
In the pre-colonial and colonial, Nigerian women never enjoyed parity with men in leadership position and the same is happening in post-colonial era. However, in spite of the patriarchal nature of our society, there is documented evidence of women participation in key leadership positions.

In the pre-colonial period, the exploits made by women are clearly documented in the literature. In the Northern part of the country, we have Queen Amina ruled in Zaria city from 1588-1890 AD or Anno Domini (Abdullahi, 1990). Then, another woman named Zainab who ruled over Dekina, Lokoja, and Okene between 1800 - 1890; and record had it that she demonstrated effective leadership qualities (Abdullahi, 1990). There are other documentations of pre-colonial women leaders too, like Queen Idia and the likes (Egharevba, 1968).

We equally have Madam Tinubu of Lagos (Williams, 1990); Moremi of Ife; Mrs. Funmilayo Ransome Kuti; and Mrs. Margaret Ekpo in the Nigerian pre-Independence political struggles of the 1950s. Mrs. Funmilayo Ransome Kuti was said to be a strong advocate and campaigner for women's rights across the country. Mrs. Margaret Ekpo, on her part, was the only female member of the seven-man committee set up in 1951 to organize a national political organization geared toward achieving self-government within five years. She became the Vice President of the Eastern House of Chiefs in 1959 (Okafor \& Akokuwebe, 2015:1). All these women were distinguished leaders during their own time. Meanwhile, it was recorded that colonialism inhibited women's participation in politics (Terwase, 2010).

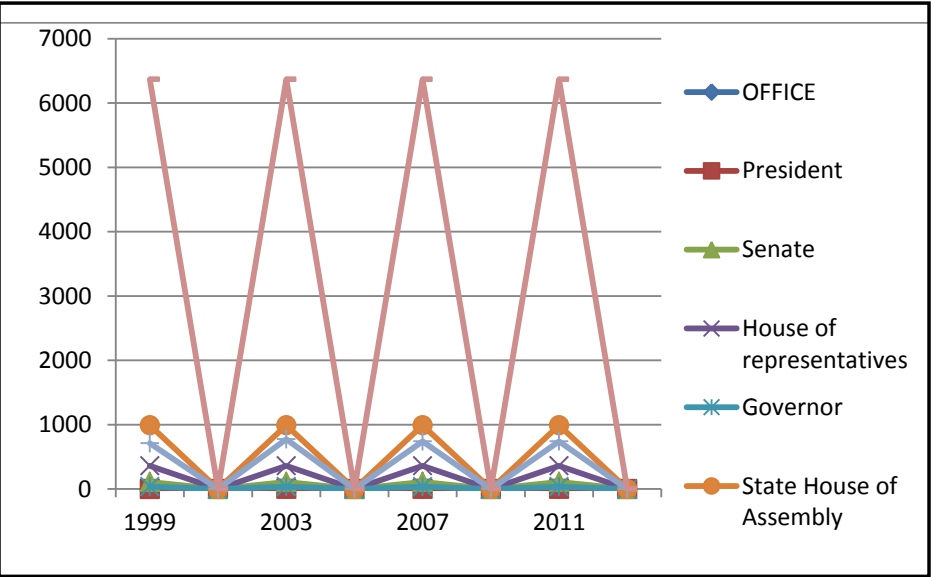

Figure 1:

Comparison of Women Appointes in Nigeria by Regimes of President Obasanjo, Musa Yar'dua, and Goodluck Ebele Jonathan (Source: S.O. Eyeh, 2011; F.O. Irabor, 2012; and C.C. Okoronkwo, 2013)

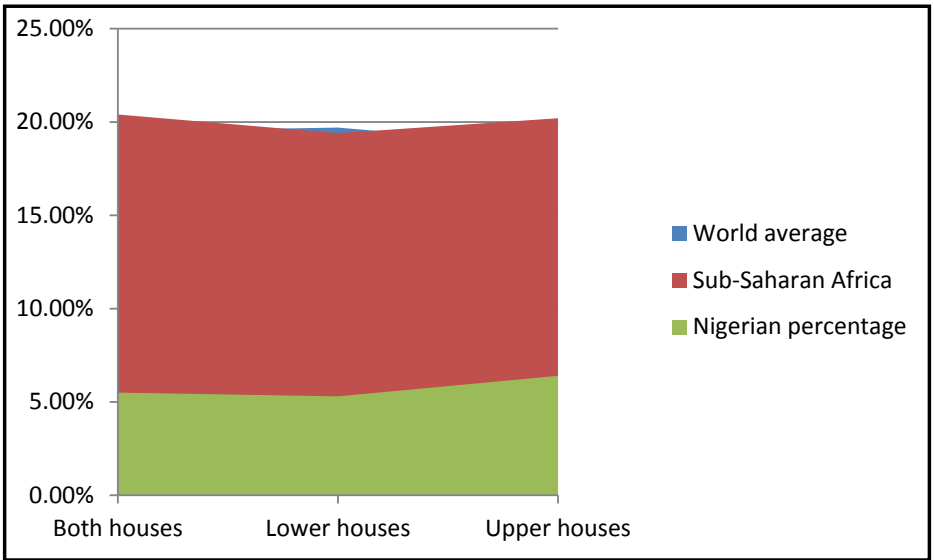

Figure 2:

Global Comparison of Percentage of Women in National Parliament

(Source: Adapted from G.A. Ogunyakin, 2015)

In spite of the facts that Nigerian women contributed significantly to the Nigerian's political independence, the post-colonial milieu was largely male dominated with few women holding insignificant public positions. Only Benice Ukuango-Kerry and Wuraola Esan were members of the 36 member senate. At the regional level, only 3 women were appointed Ministers and Commissioners. While the post-colonial military class was exclusively male, women first ladies were given opportunities at both 
the third and fourth republic (Idahosa \& Akhigbe, 2007:42-46).

The following graphs represent the level of women participation in governance in Nigeria. See figure 1 and figure 2.

From the data in figure 1 and figure 2, the following points are deducible. Firstly, women representation in the leadership position's recorded a serious boost, since the return to democratic rule in 1999 and this continued to increase with each succeeding administration. Secondly, in most instances, the women appointed to the key administrative and political positions since 1999 are noted to perform creditably.

Reports have the performance of women, such as Prof. (Mrs.) Grace AleleWilliams in the field of Mathematics education, but became the Vice Chancellor of the University of Benin - the first female Nigerian academic; late Prof. Dora Nkem Akunyili, former Director of NAFDAC (National Agency for Food and Drugs Control), who reduced the incidence of fake drugs from about $90 \%$ to $68 \%$ in 2001 ; Dr. Obiageli Ezekweseli, former senior special assistant to former President Obasanjo on Budget Monitoring and Price Intelligence Unit, otherwise known as Due Process Unit; Mrs. Ndi Okereke Onyinke, former Managing Director of the Nigerian Stock Exchange; Mrs. Evelyn Oputu, Managing Director of Nigerian Bank of Industry; Prof. Mrs. Rugayyatu Ahmad Rufai, former Minister of Education; Mrs. Ifueko Omoiqu Okauru, immediate past Executive Chairperson Federal Inland Revenue Services; and Dr. Mrs. Ngozi Okonjo Eweala doubled as a Minister of Finance during President Olusegun Obasanjo and Ebele Goodluck Jonathan administration, worked indefatigably and secured a reprieve for Nigerians external debt among others (Okafor \& Akokuwebe, 2015:2).

The enormous contributions of these women to national developments are commendable. Then, for the fact that they performed creditably well leaves no doubt about the ability and capability of women to perform, when saddled with responsibilities at all levels. Meanwhile, in spite of this notable strides recorded by some women in leadership positions in Nigeria, there have been a dramatic ethical shift among some Nigerian women in public spaces. This will be considered below.

\section{CHANGING ROLES OF WOMEN IN LEADERSHIP POSITIONS IN CONTEMPORARY NIGERIA}

Studies have shown that there is indeed a link between higher representations of women in public institutions and lower levels of corruption. Although a greater percentage of these studies tilt towards women being less corrupt than their male counterparts due to intrinsic characteristics. But, some authors have criticized this notion and one of them is Anne Marie Goetz (2013), who believes that, as the workplace becomes more feminized and women take the top leadership jobs, it cannot be assumed that women will choose less corrupt behaviors (Goetz, 2013).

Meanwhile, the reality of the situation may be quite contrary; indeed, women may be as tyrannical and oppressive as men in some instances. The real life experiences in Nigeria show that there have been quite a number of corrupt practices among women, who have held political offices in Nigeria. There are incidences of women who started off well, but veered off to "corruption street".

Today, despite the clamor by Nigerian women for more female representations in government, performances of the few that have held office shows that when it comes to corruption, gender is hardly an issue. Nigeria's most senior elected female political leader - former Speaker of the House of Representatives, Mrs. Patricia Olubunmi Etteh, was impeached on corruption grounds just months after taking oaths of office. Equally, the monumental fraud that characterized the Nigerian Stock Exchange 
under its former head, Dr. Ndidi Okereke, may never be told, except that millions of Nigerian investors lost trillions of Naira under very dubious circumstances.

The actions of the woman that fired her - Mrs. Arunma Oteh, makes one wonder what agitation for more female representations in government or leadership position is really about. Besides, there was equally the case of Mrs. Oduah, who was forced to resign because of the various controversies and scandals trailing her. The former Aviation Minister was found quilt by two panels, which probed the purchase of two bullet proofs cars by an agency under her supervision, the NCAA (Nigerian Civil Aviation Authority) for 255 millions in violation of Nigeria's public procurement and appropriation laws. She was equally involved in a certificate forgery scandal.

The former Minister was alleged to have claimed, in the resume, she submitted to the senate for her confirmation hearing that a University, which was later found to be nonexistent, awarded her a phantom for honorary doctorate degree. She also falsely claimed on the website of the Ministry of Aviation that she bagged a Master's degree from St Paul College, Lawrenceville, Virgina, USA (United States of America).

Incidentally, Nigerian women in business have also demonstrated the same uncanny ability to pilfer public funds, as the case of Mrs. Cecilia Ibru, who was convicted of stealing, near 200 billion Naira of depositor's funds, while she headed the former Oceanic Bank. These are few cases that can be mentioned here, there are many others (Mohammed, 3/4/2012).

However, the fact that some women have not played their roles correctly does not mean there couldn't be a change. There is room for encouragement and the reason why this paper is proposing the Biblical model of Esther for women occupying leadership roles in
Model of

humility

sacrifice

Model of

prayer
Model of

determination

Model of

Righteousness
Figure 3:

Esther's Religious Leadership Model

(Source: Designed by the Author)

Nigeria. There is to need to look inwardly to help our women, who are still in leadership positions and those aspiring or will be there in the nearest future.

This paper, therefore, extend the solution approach by proposing "Esther's religious leadership model”, as shown in figure 3.

Esther's religious leadership model, in figure 3, indicates that women who are leaders need to remain true to the core principles, values, and vision. A leader must have the courage and be determined to step out for others in the face of adversity. When a leader is ready to sacrifice for the well-being of others, just like Esther did, even when it seems to be a total contradiction with others, the desire of every citizens or followers will be sure.

Women leaders should know, when there is necessity to be ready to renounce selves and exert themselves for the good of others. It is important to point out that a leader needs to be a source of inspiration and motivation towards the required action. People are not likely to behave or to follow, if they are not convinced that success is attainable.

This Esther did by calling for fasting and prayer for the Israelites, of which she partook in. Also, it was noted that Esther led by example, by not asking the Israelites to do anything that she would not do. The way and manner she approached the king showed her level of compassion for others and humility. 
It takes somebody who is compassionate and humble to take such a bold step in spite of her exalted position, if it were to be someone who is selfish, the children of Israel would have been totally destroyed. She did not only understand their points of view, she was equally emphatic to their feelings and work towards nurturing and protecting them.

Lastly, the Bible recorded that she went to the inner court of the king's house with her royal apparel, not in kitchen aprons. This in away suggest that righteousness, transparency, honesty, loyalty, respect, faith, and dedication must be the garment of any person, who desires favor of men and God in any exalted positions. A leader who wants to enjoy the cooperation of others in and around him must embrace the core values of life.

\section{CONCLUSION}

Good leadership enhances and optimizes better performance and so when this is lacking the vision or the goal cannot be realized. While leadership is learned, the skills and knowledge processed by the leader can be influenced by his or her attributes, such as beliefs, values, ethics, and character. All these attributes so to say were combined by Esther to achieve the emancipation of her people from the evil plan of Haman. Although all situations are different, what did you do in one situation will not always work in another.

However, a good leader must decide the course of action, like Esther, and the leadership style to adopt for each situation. When it requires confrontation, if this is too late or too harsh or weak, the result may prove ineffective; but if action is taken on time without delay, there would be good result. Therefore, women leaders are hereby advised to always act promptly as seen in the case of Esther in this paper. ${ }^{1}$

${ }^{1}$ Statement: I, hereby, declared that this paper is my own original work and not product of plagiarism in any books or journal that have been published. The citation is stated and it is available showed in the References. This paper is never also being submitted and published by other scholarly journal.

\section{References}

Abdullahi, R. (1990). "Women in Politics: A Psychological Appraisal” in Jadesola Akande et al. [eds]. The Contribution of Women to National Development in Nigeria. Lagos: The Nigerian Association of University Women.

Atimono, E. (1981). Jindadin Jamari: An Authentic Ideology of Politics in Nigeria. Lagos: n.p. [no publisher].

Babajide, E. (2000). "Comparative Analysis of the Leadership Style of Male and Female in South Western Nigeria” in Nigerian Journal of Industrial Relations, Vol.7 \& 8 [December], pp.62-70.

Direland, R. \& M.A. Hitt. (2005). “Achieving and Maintaining Strategic Competitiveness in the $21^{\text {st }}$ Century: The Role of Strategic Leadership” in Academy of Management Executive Journal, 19(4).

Egharevba, J.U. (1968). A Short History of Benin. Ibadan: Ibadan University Press.

Eyeh, S.O. (2011). "From Myth to Consciousness: The Novel as Mimetic Mode of Women's Sociocultural and Political Transformation in Nigeria” in Journal of the Nigeria English Studies Association, Vol.13(2), pp.137-150.

Goetz, Anne Marie. (2013). No Shortcuts to Power: African Women in Politics and Policy Making. London: Zed Books.

Idahosa, S.A. \& P. Jack Akhigbe. (2007). “The Global Mobilisation of Women for Active Participation in Politics: Challenges for the Nigerian Women in the $21^{\text {st }}$ Century” in BIU: Journal of Social and Management Sciences, 1(1), pp.42-66.

Irabor, F.O. (2012). “Review of Women's Participation and Performance at the 2011 General Elections in Nigeria”. Available online also at: $\underline{w w w}$. baobwomen.org [accessed in Ado-Ekiti, Nigeria: December 1, 2015].

Kruse, K. (2013). “What is Leadership?” in Forbes Magazine, p.3.

Levy, P. Yukh. (2010). Industrial Organizational Psychology: Understanding the Work Place. New York: NY Worth Publishers, $3^{\text {rd }}$ edition.

Lockyer, Herbert. (1971). The Woman of the Bible. Michigan: Zondervan Publishing House, Grand Rapids.

Longe, O. (2015). "Women Leadership: Hope for the Preferred Future in Nigeria”. Paper presented at the $7^{\text {th }}$ Conference of Women in Administration, organized by IPAN [Institute of Public Administration of Nigeria], Abuja, Nigeria, $25^{\text {th }}-27^{\text {th }}$ July.

Mohammed, Saude Amina. (2012). "Women, Corruption, and Governance” in Nigeria INTEL. Ado-Ekiti, Nigeria: 3 April.

Northouse, G. (2007). Leadership: Theory and 
Practice. Thousand Oaks, C.A.: Sage Publications, $3^{\text {rd }}$ edition.

Ogunyakin, G.A. (2015). "The Gendering of Politics in Nigeria, Part-1”. Available online also at: http://www.makeeverwomancount.org/index.php [accessed in Ado-Ekiti, Nigeria: December 1, 2015].

Okafor, E. Emmanuel \& M.E. Akokuwebe. (2015). "Women Leadership in Nigeria: Challenges and Prospects” in Development Country Studies, 5(4), ISSN 2224-607X (print) and ISSN 2225-0565 (online).

Okoronkwo, C.C. (2013). "Gender Inequalities in Nigerian Politics”. Unpublished M.A. Thesis in Partial Fulfillment of the Requirement for the Degree of Masters of Arts in Corporate and Public Communication, Seton Hall University.

Olayiwola, A.R.O. (2013). "Leadership Corruption and Governance in Nigeria” in Journal of
Education and Leadership Developments, Vol.5(2). Osuntokun, J. (1987). "Leadership and Development” in Development Outlook, Vol.1, No.9.

Terwase, Sampson Isaac. (2010). “Gender and Corruption: Understanding the Increasing Role of Nigerian Women in Corrupt Practice”. Available online also at: www.Readperiodicals. Com/2010/2/218771328.html [accessed in AdoEkiti, Nigeria: December 1, 2015].

Williams, G. Alele. (1990). “The Contribution of Women to National Development in Nigeria Education” in Jadesola Akande et al. [eds]. The Contribution of Women to National Development in Nigeria. Lagos: The Nigerian Association of University Women.

Zeitchik, S. (2012). "10 Ways to Define Leadership” in Business News Daily. 
ADESANYA IBIYINKA OLUSOLA,

Esther: Biblical Model for Women Leadership Role

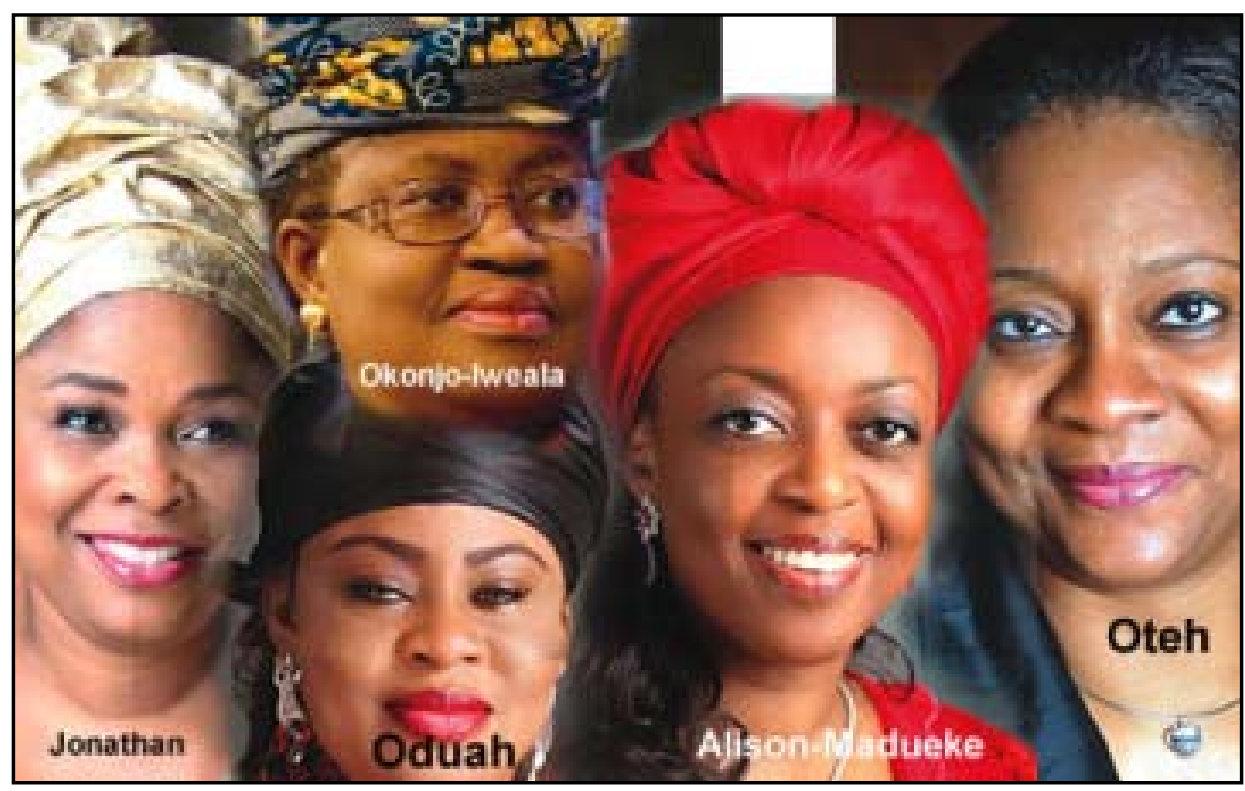

Women and Leadership in Nigeria

(Source: http://www.informationng.com, 8/1/2016)

Good leadership enhances and optimizes better performance and so when this is lacking the vision or the goal cannot be realized. While leadership is learned, the skills and knowledge processed by the leader can be influenced by his or her attributes, such as beliefs, values, ethics, and character. All these attributes so to say were combined by Esther to achieve the emancipation of her people from the evil plan of Haman. Although all situations are different, what did you do in one situation will not always work in another. 